Finanse, Rynki Finansowe, Ubezpieczenia nr 4/2016 (82), cz. 2

\title{
IPO Firms' Earnings Quality in Poland Around the Crisis
}

\author{
Joanna Lizińska, Leszek Czapiewski*
}

\begin{abstract}
Purpose - The study examines the properties of discretionary accruals for Polish companies around initial public offerings (IPOs) in the pre and post-crisis years.

Design/methodology/approach - The subsamples covered IPO firms going public before the crisis (20022006) and after the height of the crisis (2009-2013). Discretionary accruals as proxies for earnings quality were estimated according to the DeAngelo model and the modified Jones model in the cross-sectional version.

Findings - IPO firms have positive, relatively high issue-year abnormal accruals followed by negative abnormal accruals in subsequent years. The results suggest that IPO firms engage in more aggressive incomeincreasing earnings management.

Originality/value -The study covers IPOs on the Warsaw Stock Exchange in Poland. The earnings quality of Polish IPOs around this issue has not been examined so far.
\end{abstract}

Keywords: capital market, equity offering, IPO, emerging market, earnings quality, earnings management

\section{Introduction}

Earnings quality has long been of interest to researchers, regulators and practitioners. Dechow and Schrand (2004) stipulated a high quality earnings number should reflect current operating performance, should be a good indicator of future operating performance and should also accurately annuitize the intrinsic company value. Earnings quality is important as it may have predictive power for future equity prices (Chan et al. 2001). Earnings quality often appears in connection with the concept of earnings management, also earnings manipulation. We follow the definition of Healy and Wahlen (1999) that "earnings management occurs when managers use judgment in financial reporting and in structuring transactions to alter financial reports to either mislead some stakeholders about underlying economic performance of the company or to influence contractual outcomes that depend on reported accounting numbers".

Although many accounting standards have been introduced to provide more relevant information to the capital market and to raise earnings quality, there is still considerable room for managerial discretion. Accounting rules enable managers to exercise judgement

\footnotetext{
* dr Joanna Lizińska, Uniwersytet Ekonomiczny w Poznaniu, e-mail: joanna.lizinska@ue.poznan.pl; dr Leszek Czapiewski, Uniwersytet Ekonomicznyw Poznaniu, e-mail: leszek.czapiewski@ue.poznan.pl.
} 
to some extent in preparing financial statements. Managerial discretion in reporting some accounting numbers should generally be used to make financial statements more informative. However, there is sometimes enticement to use it in a quite opposite manner to mislead some stakeholders.

Earnings are the kind of fundamental information about a company that the market usually fixates on. There have been many empirical studies that reported a strong market reaction to earnings announcements (e.g. Hotchkiss, Strickland 2003; Francis, Schipper, Vincent 2002; Bernard, Thomas 1989). It demonstrates the importance of a company's profitability.

A great deal of attention is usually devoted to company financial performance, especially earnings, around important company events. The initial public offering (IPO) is one such a milestone in company life cycles and thus attracts a lot of investor attention. Hence, managers are tempted to window-dress by overstating performance around IPO. Previous empirical studies for developed markets supported the hypothesis that managers opportunistically inflate earnings to influence IPO pricing (Theo, Welch, Wong 1998). Alternatively, IPO firms might be induced to report more conservatively because of higher reporting standards for public companies and better monitoring (Ball, Shivakumar 2005 and 2008). The conflicting views argue in favour of an empirical examination of IPO firms' earnings quality around issue time. This is especially interesting for the Polish capital market which is still an emerging one and as such is characterised by specific corporate governance. The Warsaw Stock Exchange (WSE) for several years has also been one of the most dynamically developing European markets.

The last financial crisis called for a fundamental reassessment of accounting standards as well as practice and corporate governance rules. Accounting standards and corporate governance arrangements have been shown to have many weaknesses still (Kirkpatrick 2009). This raises the question of whether lessons had been learned from the last financial in terms of earnings quality. The importance of the discussion on earnings management in the context of the last financial crisis has been stressed by many academics, in Poland, among others, Gajdka (2012).The subsamples in this research covered the years before and after the height of the crisis.

Managers obviously do not boast of the using of earnings manipulation practices, so it is not possible to measure earnings management directly. This makes the detection of earnings management a hard task for researchers. It would be ideal to observe the accounting choices and decisions of managers to assess if their discretion was used either in order to reflect the actual financial condition of the company, or conversely - to mislead outsiders. However, it is impossible to observe the accounting numbers that should have been reported without managerial interference. Hence, a broad set of earnings quality proxies such as accruals, smoothness, timeliness, or loss avoidance have been developed and applied in empirical studies. Here, the research approach based on accruals was adopted. Accruals modify the timing of earnings and as such they are desirable when some window dressing techniques are planned to be introduced. 
The research focused on assessing the earnings quality of Polish IPO firms around the issue the time before and after the height of the financial crisis.

The study was financed by the National Science Centre, Poland as a research project (2014/13/B/HS4/01556).The rest of the paper is structured in the following way. In the next section the research sample is described. Section 2 describes the methodology. In section 3 estimates of discretionary accruals are discussed. The last section states the conclusions.

\section{Research sample}

The research sample covers initial public offerings (IPOs) on the Polish main stock market, mainly the Warsaw Stock Exchange (WSE). The sample included only such offerings that were connected with a new common stock issuance, without prior trading history on alternative markets. The source of the data was Notoria Serwis, the official site of the WSE (http:// www.gpw.pl) and www.gpwinfostrefa.pl. First of all, it was essential to prepare an original, comprehensive database covering financial statements, also for delisted companies.

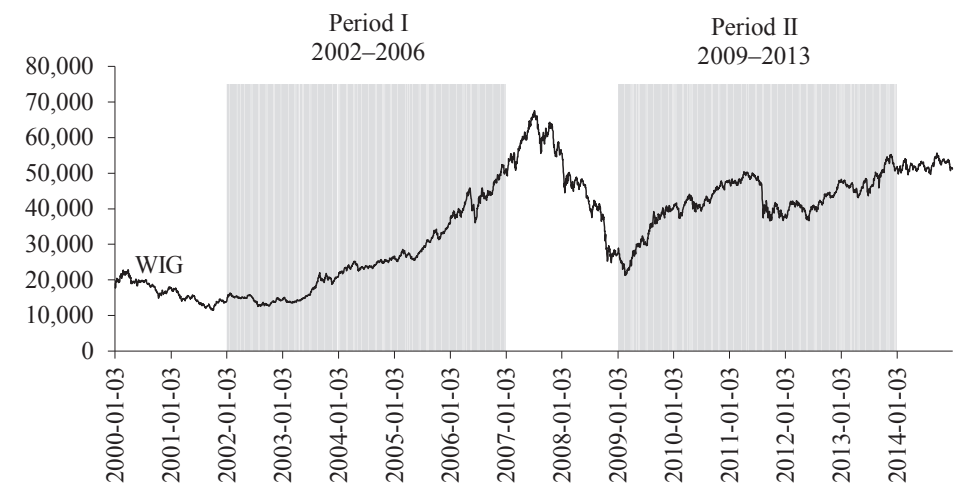

Figure 1. WIG index during the research sub-periods

Source: own.

The original sample consisted of 241 IPOs from 2002 to 2013. Then, non-financial IPOs were divided into research subsamples according to the issue year. Two five-year sub-periods were distinguished: Period I covered 97 IPOs from the years before the crisis (from 2002 to 2006). Period II covered 60 issues from the years after the height of the crisis (starting from 2009 to 2013). The mean daily WIG index return for Period I and II was $0.11 \%$ and $0.06 \%$, respectively. The cumulative daily return on the index was $136.6 \%$ and $73.4 \%$ for Period I and II, respectively (with the buy-and-hold approach it was $260.2 \%$ vs. $81.0 \%$ ). The WIG index changes in both research sub-periods were illustrated in Figure 1.

The descriptive statistics for both research subsamples are given in Table 1. 
Table 1

Descriptive statistics for the IPO sample for the year before going public (thousand PLN)

\begin{tabular}{|c|c|c|}
\hline & Period I: IPOs from 2002-2006 & Period II: IPOs from 2009-2013 \\
\hline \multicolumn{3}{|c|}{ Panel A: Return on sales } \\
\hline Mean & $14.3 \%$ & $13.5 \%$ \\
\hline Median & $6.2 \%$ & $10.1 \%$ \\
\hline Observations & 96 & 60 \\
\hline \multicolumn{3}{|c|}{ Panel B: Financial leverage } \\
\hline Mean & $84.6 \%$ & $67.7 \%$ \\
\hline Median & $74.5 \%$ & $55.3 \%$ \\
\hline Observations & 90 & 56 \\
\hline \multicolumn{3}{|l|}{ Panel C: Assets } \\
\hline Mean & $\mid 1,268,769$ & $3,723,750$ \\
\hline Median & 54,730 & 135,474 \\
\hline Observations & 94 & 59 \\
\hline
\end{tabular}

Source: own calculations.

\section{Earnings quality proxies and methodology}

The proxies of earnings quality can be threefold. They can be connected with properties of earnings, investor responsiveness to earnings and external indicators of earnings misstatements (Dechow, Ge, Schrand 2010). The present research touches upon the first area, which is actually a very broad one. It can involve such earnings quality proxies as earnings persistence (e.g. Sloan 1996), earnings smoothness (e.g. Tucker, Zarowin 2006), asymmetric timelines (e.g. Basu 1997), target beating (e.g. Burgstahler, Dichev 1997) and abnormal accruals (e.g. Jones 1991). This research concentrates on the last group of proxies.

The income level is one of those accounting numbers that most investors are strongly interested in. This makes managers eager to employ some window dressing techniques to make the income more appealing. Such a temptation proves to be great especially before some important company events, when the firm's financial condition both attracts a lot of attention and seems to influence investors' decisions. The initial public offering is certainly one such event. Earnings are supposed to be less informative in the IPO year with possible consequences for the surrounding years. That is why earnings quality is observed around issue time, mainly for the year of going public $\left({ }^{\mathrm{Y} 0}\right)$, for the two preceding years $(\mathrm{Y}-1$ and $\mathrm{Y}-2$ and for the consecutive years $(\mathrm{Y}+1, \mathrm{Y}+2, \mathrm{Y}+3$, and $\mathrm{Y}+4)$.

Total real accruals are calculated as the change in non-cash net working capital less depreciation (Jones 1991):

$$
A C C_{i t}=\left(\Delta C A_{i t}-\Delta C a s h_{i t}\right)-\Delta C L_{i t}-D_{e p r},
$$


where:

$A C C_{i t}-$ total accruals for $i$ company in year $t$, scaled by lagged assets,

$\Delta C A_{i t}$ - change in current assets for $i$ company in year $t$, scaled by lagged assets, where the change $(\Delta)$ is computed between time $t$ and $t-1$,

$\Delta$ Cash $_{i t}$ - change in cash for $i$ company in year $t$, scaled by lagged assets, where the change $(\Delta)$ is computed between time $t$ and $t-1$,

$\Delta C L_{i t}$ - change in current liabilities for $i$ company in year $t$, scaled by lagged assets,

Depr $_{i t}-$ depreciation expense for $i$ company in year $t$, scaled by lagged assets.

Jones (1991) proposed a decomposition of accounting earnings into:

where:

$$
T A C C_{i t}=N D A C C_{i t}+D A C C_{i t},
$$

$N D A C C_{i t}$ - non-discretionary accruals for $i$ company in year $t$, scaled by lagged assets,

$D A C C_{i t}-$ discretionary accruals for $i$ company in year $t$, scaled by lagged assets.

Non-discretionary (normal) accruals are the adjustments to company cash flows that are mandated by legislative bodies. The obligation to depreciate fixed assets in a systematic manner is an example of this. Discretionary (abnormal) accruals are not obligatory, but are selected by managers. For example, the company's managers can choose one of the accepted methods of depreciation. As such, discretionary accruals enable managers to voluntarily transfer earnings between reporting periods. Discretionary accruals are a commonly used proxy for earnings quality (e.g. Dechow, Schrand 2004; Ball, Shivakumar 2008).

DeAngelo (1986) proposed abnormal accruals calculations, as these should properly reflect the part of total accruals that is connected with unusual events and the earnings management practices around them. The difference between real accruals and estimated (normal) accruals $E\left(A C C_{i t}\right)^{D}$ measures the scale of opportunistic discretionary accruals. DeAngelo's model generally assumes that non-discretionary accruals are typical for a company. Hence, the changes in the level of total accruals should be a consequence of a fluctuation in discretionary accruals. Total accruals from the prior period are used to approximate to normal accruals:

$$
E\left(A C C_{i t}\right)^{D}=A C C_{i t-1}
$$

The DeAngelo model measures discretionary accruals without error if non-discretionary accruals are constant in time. However, the level of non-discretionary accruals can vary over time, in response to changes in economic circumstances. Jones (1991) proposed a model that allows controlling for the effect of such changes. Then, the normal accruals should be estimated as:

$$
N D A C C_{i t}^{J}=\alpha_{i 1}\left(\frac{1}{A_{i t-1}}\right)+\alpha_{i 2}\left(\Delta R E V_{i t}\right)+\alpha_{i 3}\left(P P E_{i t}\right),
$$


where:

$A_{i t-1} \quad-$ total assets for company $i$ in at time $t-1$,

$\triangle R E V_{i t}-$ revenues for company $i$ in year $t$ less revenues in year $t-1$ scaled by lagged assets,

$P P E_{i t}$ - gross property, plant and equipment in year $t$ for company $i$ scaled by lagged assets,

$\alpha_{i 1}, \alpha_{i 2}, \alpha_{i 3}$ - firm-specific parameters.

The parameters of $\alpha_{i 1}, \alpha_{i 2}, \alpha_{i 3}$, for company $i$ in year $t$ should be estimated according to:

$$
E\left(A C C_{i t}\right)^{J}=a_{i 1}\left(\frac{1}{A_{i t-1}}\right)+a_{i 2}\left(\Delta R E V_{i t}\right)+a_{i 3}\left(P P E_{i t}\right)+\vartheta_{i t},
$$

where $\alpha_{i 1}, \alpha_{i 2}, \alpha_{i 3}$, are the estimated levels of parameters $\alpha_{i 1}, \alpha_{i 2}, \alpha_{i 3}$ according to the ordinary least square regression.

The cross-sectional version of the model should be used for the IPO sample as the timeseries version would be difficult to implement because of the lack of data for longer time series for the pre-offering period for IPO firms (compare DeFond and Jiambalvo 1994; Subramanyam 1996; DuCharme, Malatesta, Sefcik 2001).

The traditional Jones model may underestimate discretionary accruals if firms manage earnings by changing the time location of sales. Hence, the modified Jones model is applied (Dechow, Sloan, Sweeney 1995). Then, the normal accruals according to the modified Jones model in the cross-sectional version are estimated as:

$$
E\left(A C C_{i t}\right)^{M J}=\alpha_{i 1}\left(\frac{1}{A_{i t-1}}\right)+\alpha_{i 2}\left(\Delta R E V_{i t}-\Delta R E C_{i t}\right)+\alpha_{i 3}\left(P P E_{i t}\right),
$$

where $\triangle R E C_{i t}-$ receivables for company $i$ in year $t$ less receivables in year $t-1$ scaled by lagged assets.

The sample is restricted to non-financial IPO firms with complete data for real and estimated accruals. An additional requirement is connected with the procedure for the estimation of parameters in OLS regressions in the modified Jones model and ensures the benchmark industry sector consists of at least five companies. It is also restricted for each IPO firm up to the second year after going public to be included in the benchmark sector to estimate non-discretionary accruals for another IPO.

Total, discretionary and non-discretionary accruals and their components are scaled by lagged assets to reduce the problem of heteroscedasticity (Ronen, Yaari 2008). To minimise the potentially detrimental effect of extreme observations, possible outliers were found and eliminated with the use of the interquartile range $(I Q R)$. The lower bound was set at 
$Q_{1}-1.5 \times I Q R$ and the upper bound at $Q_{3}+1.5 \times I Q R$. The Shapiro-Wilk test was used to test the distribution normality of accruals. Both conventional parametric and non-parametric tests were employed, namely the Student t-test and the Wilcoxon signed-rank test. The distribution for IPOs from Period I and Period II was compared with the t-test for two samples and the Mann-Whitney U test.

\section{Discretionary accruals before and after the height of the crisis}

The average properties of discretionary accruals around IPO according to the DeAngelo model and the modified Jones model in the cross-sectional version are presented in Figure 2 and 3 , respectively.
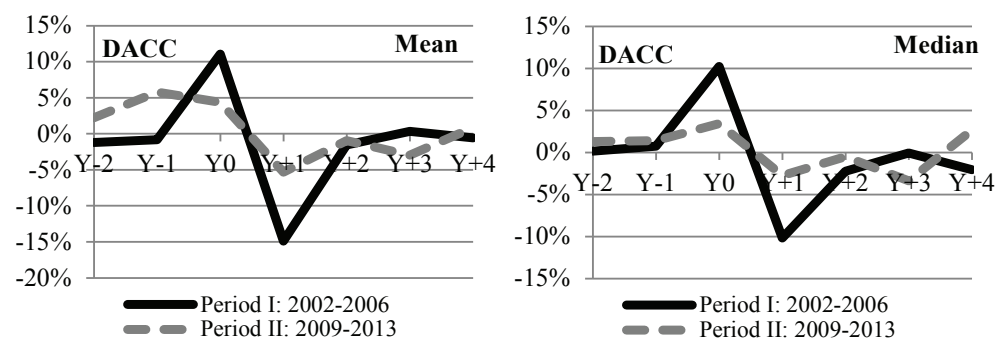

Figure 2. Average discretionary accruals in sub-periods according to the DeAngelo model Source: own calculation.

The IPO firms have positive issue-year abnormal accruals, followed by negative abnormal accruals in subsequent years. The detailed properties of discretionary accruals around the IPO are presented in Table 2 and 3.
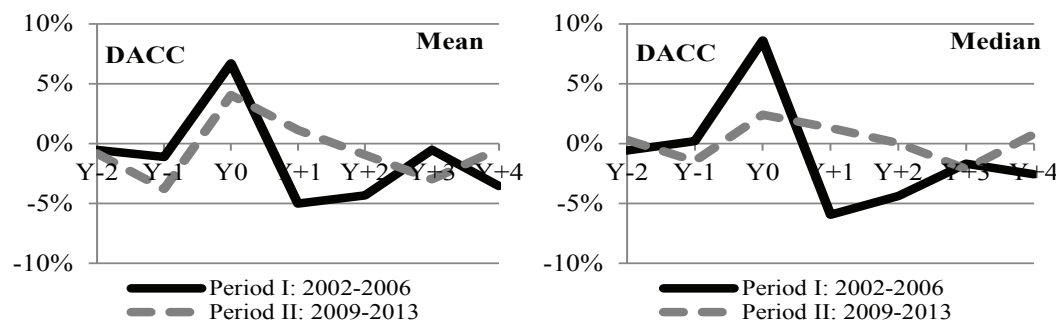

Figure 3. Average discretionary accruals in sub-periods according to the modified Jones model Source: own calculation. 
Table 2

Discretionary accruals for initial public offerings around the issue year ( $\mathrm{Y} 0$ versus $\mathrm{Y}-2)$

\begin{tabular}{|c|c|c|c|c|}
\hline & & & \multirow{2}{*}{\multicolumn{2}{|c|}{ Period II: 2009-2013 }} \\
\hline & \multicolumn{2}{|c|}{ Period I: 2002-2006 } & & \\
\hline & $\mathrm{Y}-2$ & Y0 & $\mathrm{Y}-2$ & Y0 \\
\hline \multicolumn{5}{|c|}{ Panel A: Discretionary accruals according to the DeAngelo model } \\
\hline Average & $-1.23 \%$ & $11.05 \%$ & $2.23 \%$ & $4,38 \%$ \\
\hline Median & $0.16 \%$ & $10.24 \%$ & $1.29 \%$ & $3,41 \%$ \\
\hline Standard deviation & $11.31 \%$ & $19.90 \%$ & $25.32 \%$ & $15,31 \%$ \\
\hline Skewness & -0.29 & -0.11 & -0.35 & $-0,07$ \\
\hline Kurtosis & -0.40 & -0.24 & 0.12 & 0,70 \\
\hline p-value & 0.5776 & 0.0000 & 0.6983 & 0,0675 \\
\hline (t-stud) & & $* * *$ & & $*$ \\
\hline $\mathrm{p}$-value & 0.6964 & 0.0000 & 0.6215 & 0,0342 \\
\hline (WSR) & & $* * *$ & & $* *$ \\
\hline p-value & 0.7648 & 0.4059 & 0.5089 & 0,5190 \\
\hline \multicolumn{5}{|l|}{ (Shapiro-Wilk) } \\
\hline Observations & 27 & 82 & 20 & 43 \\
\hline $\mathrm{p}$-value for difference & 0.0002 & & 0.7278 & \\
\hline (t-stud $-\mathrm{Y} 0 / \mathrm{Y}-2$ samples) & $* * *$ & & & \\
\hline $\mathrm{p}$-value for difference & 0.0008 & & 0.6236 & \\
\hline (U test $-\mathrm{Y} 0 / \mathrm{Y}-2$ samples) & $* * *$ & & & \\
\hline \multicolumn{5}{|c|}{ Panel B: Discretionary accruals according to the modified Jones model } \\
\hline Average & $-0.55 \%$ & $6.70 \%$ & $-0,83 \%$ & $4,04 \%$ \\
\hline Median & $-0.58 \%$ & $8.61 \%$ & $0,30 \%$ & $2,41 \%$ \\
\hline Standard deviation & $16.02 \%$ & $22.58 \%$ & $13,23 \%$ & $12,55 \%$ \\
\hline Skewness & -0.22 & -0.35 & 0,41 & 0,41 \\
\hline Kurtosis & 0.36 & 0.12 & 0,36 & 0,76 \\
\hline p-value & 0.7894 & 0.0134 & 0,6925 & 0,0304 \\
\hline (t-stud) & & $* *$ & & $* *$ \\
\hline p-value & 0.8664 & 0.0061 & 0,5185 & 0,0351 \\
\hline (WSR) & & $* * *$ & & $* *$ \\
\hline $\begin{array}{l}\text { p-value } \\
\text { (Shapiro-Wilk) }\end{array}$ & 0.1290 & 0.3143 & 0,5148 & 0,1908 \\
\hline Observations & 62 & 73 & 40 & 48 \\
\hline $\mathrm{p}$-value for difference & 0.0317 & & 0.0817 & \\
\hline (t-stud $-\mathrm{Y} 0 / \mathrm{Y}-2$ samples) & $* *$ & & $*$ & \\
\hline $\mathrm{p}$-value for difference & 0.0124 & & 0.0777 & \\
\hline (U test $-\mathrm{Y} 0 / \mathrm{Y}-2$ samples) & $* * *$ & & $*$ & \\
\hline
\end{tabular}

Notes: significance at the $1 \%(* * *), 5 \%(* *)$ and $10 \%\left({ }^{*}\right)$ level.

Source: own calculations. 
Table 3

Discretionary accruals for initial public offerings around the issue year ( $\mathrm{Y} 0$ versus $\mathrm{Y}+1)$

\begin{tabular}{|c|c|c|c|c|}
\hline & \multirow{2}{*}{\multicolumn{2}{|c|}{ Period I: 2002-2006 }} & \multirow{2}{*}{\multicolumn{2}{|c|}{ Period II: 2009-2013 }} \\
\hline & & & & \\
\hline & Y0 & $\mathrm{Y}+1$ & Y0 & $\mathrm{Y}+1$ \\
\hline \multicolumn{5}{|c|}{ Panel A: Discretionary accruals according to the DeAngelo model } \\
\hline Average & $11.05 \%$ & $-14.90 \%$ & $4.38 \%$ & $-5.32 \%$ \\
\hline Median & $10.24 \%$ & $-10.20 \%$ & $3.41 \%$ & $-2.76 \%$ \\
\hline Standard deviation & $19.90 \%$ & $27.00 \%$ & $15.31 \%$ & $12.72 \%$ \\
\hline Skewness & -0.11 & -0.34 & -0.07 & -0.53 \\
\hline Kurtosis & -0.24 & 0.25 & 0.70 & 0.95 \\
\hline p-value & 0.0000 & 0.0000 & 0.0675 & 0.0090 \\
\hline (t-stud) & $* * *$ & $* * *$ & $*$ & $* * *$ \\
\hline p-value & 0.0000 & 0.0000 & 0.0342 & 0.0086 \\
\hline (WSR) & $* * *$ & $* * *$ & $* *$ & $* * *$ \\
\hline \multicolumn{5}{|l|}{ (Shapiro-Wilk) } \\
\hline Observations & 82 & 83 & 43 & 43 \\
\hline p-value for difference & 0.0000 & & 0.0020 & \\
\hline (t-stud - Y0/Y + 1 samples) & $* * *$ & & $* * *$ & \\
\hline $\mathrm{p}$-value for difference & 0.0000 & & 0.0007 & \\
\hline (U test $-\mathrm{Y} 0 / \mathrm{Y}+1$ samples $)$ & $* * *$ & & $* * *$ & \\
\hline \multicolumn{5}{|c|}{ Panel B: Discretionary accruals according to the modified Jones model } \\
\hline Average & $6.70 \%$ & $-5.03 \%$ & $4,04 \%$ & $1,13 \%$ \\
\hline Median & $8.61 \%$ & $-5.95 \%$ & $2,41 \%$ & $1,30 \%$ \\
\hline Standard deviation & $22.58 \%$ & $15.68 \%$ & $12,55 \%$ & $11,71 \%$ \\
\hline Skewness & -0.35 & -0.08 & 0,41 & 0,04 \\
\hline Kurtosis & 0.12 & 0.72 & 0,76 & 0,08 \\
\hline p-value & 0.0134 & 0.0066 & 0,0304 & 0,4969 \\
\hline (t-stud) & $* *$ & $* * *$ & $* *$ & \\
\hline p-value & 0.0061 & 0.0036 & 0,0351 & 0,4632 \\
\hline (WSR) & $* * *$ & $* * *$ & $* *$ & \\
\hline p-value & 0.3143 & 0.0490 & 0,1908 & 0,9823 \\
\hline (Shapiro-Wilk) & & $* *$ & & \\
\hline Observations & 73 & 76 & 48 & 50 \\
\hline $\mathrm{p}$-value for difference & 0.0004 & & 0.2389 & \\
\hline (t-stud - Y0/Y + 1 samples) & $* * *$ & & & \\
\hline $\mathrm{p}$-value for difference & 0.0001 & & 0.3500 & \\
\hline (U test $-\mathrm{Y} 0 / \mathrm{Y}+1$ samples $)$ & $* * *$ & & & \\
\hline
\end{tabular}

Notes: significance at the $1 \%(* * *), 5 \%(* *)$ and $10 \%(*)$ level.

Source: own calculations. 
The levels of discretionary accruals in the IPO year (Y0) seem to be positive, and much higher in the pre-crisis period. This is generally treated in the literature as proof of engaging in aggressive income-increasing earnings management. In Period I, the distribution of abnormal accruals was significantly different in the IPO year $(\mathrm{Y} 0)$ in comparison to the period before going public $(\mathrm{Y}-2)$ and in the IPO year in comparison to the subsequent year $(\mathrm{Y}+2)$. The analogous differences for IPOs from the years after the peak of the crisis are mixed, as the results were not robust with respect to different earnings quality proxies.

\section{Conclusions}

This study examined the properties of discretionary accruals around initial public offerings (IPOs) in the pre- and post-crisis years. The sample covered IPO firms going public on the Warsaw Stock Exchange in Poland before the crisis (2002-2006) and after the height of the crisis (2009-2013). Abnormal accruals approximated to earnings quality. Non-discretionary accruals were estimated according to the DeAngelo model and the modified Jones model in the cross-sectional version.

Positive discretionary accounting accrual adjustments can be interpreted as proof of artificially inflated reported earnings relative to real cash flows. Polish IPO firms had positive, relatively high issue-year abnormal returns, followed by negative abnormal accruals in subsequent years. Such results are usually interpreted in the literature as suggesting that IPO firms engaged in more aggressive income-increasing earnings management. The level of discretionary accruals seems to be lower for IPOs offered during the post-crisis years in comparison to the pre-crisis period.

As this research is the first study testing for earnings quality in Polish IPO firms, there are still many questions left unanswered. The research did not evidence whether managers use their accounting discretion to maximize the firms value, or for their selfish enrichment at the expense of stockholders. Additionally, the discussion on the methods of empirical testing has to be continued in future with the emphasis on the problems with estimating discretionary accruals in the IPO year, errors in estimating discretionary accruals from balance sheet data or the use of pre-IPO assets as a deflator. The methods of discretionary accruals estimation around large transactions as a measure for earnings quality are still a challenge for future research.

\section{References}

Ball R., Shivakumar L. (2005). Earnings quality in UK private firms: comparative loss recognition timeliness. Journal of Accounting and Economics, 39, 83-128.

Ball R., Shivakumar L. (2008). Earnings quality at initial public offerings. Journal of Accounting and Economics, 45 (2), 324-349.

Basu S. (1997). The conservatism principle and the asymmetric timeliness of earnings. Journal of Accounting and Economics, 24 (1), 3-37. 
Bernard V.L., Thomas J.K. (1989). Post-earnings-announcement drift: delayed price response or risk premium? Journal of Accounting Research, 1-36.

Burgstahler D., Dichev I. (1997). Earnings management to avoid earnings decreases and losses. Journal of Accounting and Economics, 24 (1), 99-126.

Chan K., Chan L.K., Jegadeesh N., Lakonishok J. (2001). Earnings quality and stock returns. National Bureau of Economic Research (No. w8308).

DeAngelo L.E. (1986). Accounting numbers as market valuation substitutes: A study of management buyouts of public stockholders. Accounting Review, 400-420.

Dechow P., Ge W., Schrand C. (2010). Understanding earnings quality: A review of the proxies, their determinants and their consequences. Journal of Accounting and Economics, 50 (2), 344- 401.

Dechow P.M., Schrand C.M. (2004). Earnings quality. Research Foundation of CFA Institute, USA.

Dechow P.M., Sloan R.G., Sweeney A.P. (1995). Detecting earnings management. Accounting Review, $193-225$.

DeFond M.L., Jiambalvo J. (1994). Debt covenant violation and manipulation of accruals. Journal of Accounting and Economics, 17 (1), 145-176.

DuCharme L.L., Malatesta P.H., Sefcik S.E. (2001). Earnings management: IPO valuation and subsequent performance. Journal of Accounting, Auditing \& Finance, 16 (4), 369-396.

Francis J., Schipper K., Vincent L. (2002). Expanded disclosures and the increased usefulness of earnings announcements. Accounting Review, 77 (3), 515-546.

Gajdka J. (2012). Kształtowanie zysków w przedsiębiorstwach w kontekście kryzysu finansowego. Zeszyty Naukowe Uniwersytetu Szczecińskiego. Finanse. Rynki finansowe. Ubezpieczenia, 51, 303-311.

Healy P.M. (1985). The effect of bonus schemes on accounting decisions. Journal of Accounting and Economics, 7 (1), 85-107.

Healy P.M., Wahlen J.M. (1999). A review of the earnings management literature and its implications for standard setting. Accounting Horizons, 13 (4), 365-383.

Hotchkiss E.S., Strickland D. (2003). Does shareholder composition matter? Evidence from the market reaction to corporate earnings announcements. Journal of Finance, 58 (4), 1469-1498.

Jones J.J. (1991). Earnings management during import relief investigations. Journal of Accounting Research, 193228.

Kirkpatrick G. (2009). The corporate governance lessons from the financial crisis. OECD Journal: Financial Market Trends, 1, 61-87.

Ronen J., Yaari V. (2008). Earnings management. Springer US.

Sloan R. (1996). Do stock prices fully reflect information in accruals and cash flows about future earnings? Accounting Review, 71 (3), 289-315.

Subramanyam K.R. (1996). The pricing of discretionary accruals. Journal of Accounting and Economics, 22 (1), 249-281.

Teoh S., Welch I., Wong T. (1998). Earnings management and the subsequent market performance of initial public offerings. Journal of Finance, 53, 1935-1974.

Tucker J.W., Zarowin P.A. (2006). Does income smoothing improve earnings informativeness? Accounting Review, $81(1), 251-270$.

\section{JAKOŚĆ ZYSKÓW SPÓŁEK DEBIUTUJĄCYCH NA GPW W OKRESIE OKOLOKRYZYSOWYM}

Streszczenie: $\mathrm{Cel}$ - Celem badań była odpowiedź na pytanie, czy dla spółek debiutujących w Polsce zaobserwować można było działania polegające na zarządzaniu zyskami w okresach okołoemisyjnych w latach przed i po kryzysie.

Metodologia badania - Badania prowadzono dla spółek dokonujących pierwotnych emisji akcji (IPO) w okresie przed kryzysem (2002-2006) i po szczycie kryzysu finansowego (2009-2013). Za miernik jakości zysków przyjęto poziom ponadnormalnych przesunięć międzyokresowych (discretionary accruals). W tym celu wykorzystany został model DeAngelo i zmodyfikowany model Jones w wersji międzysektorowej.

Wynik - W roku wejścia na giełdę zaobserwowano dodatni, relatywnie wysoki poziom ponadnormalnych korekt międzyokresowych dla debiutujących spółek, któremutowarzyszył negatywny ich poziom w kolejnych latach. Takie wyniki mogą świadczyć o osłabieniu jakości zysków w związku ze zjawiskiem manipulowania zyskami w okresach okołoemisyjnych. 
Oryginalność/wartość - Badaniami objęto Giełdę Papierów Wartościowych w Warszawie, dla którego to rynku jakość zysków dla firm dokonujących IPO nie była dotychczas przedmiotem badań empirycznych.

Słowa kluczowe: rynek kapitałowy, emisja akcji, IPO, rynek wschodzący, jakość zysków, zarządzanie zyskami

\section{Citation}

Lizińska J., Czapiewski L. (2016). IPO Firms’ Earnings Quality in Poland Around the Crisis. Finanse, Rynki Finansowe, Ubezpieczenia, 4 (82/2), 201-212. DOI: 10.18276/frfu.2016.4.82/2-16. 